This is the authors' original version (AOV). This article has been accepted for publication in Notes \& Queries Published by Oxford University Press.

\author{
Alpo Honkapohja \\ 27 Hugh Miller Place \\ Edinburgh Scotland EH3 5JG
}

Lori Jones

4762 Homesteaders Road

Ottawa ON Canada K0A 1X0

\title{
FROM PRACTICA PHISICALIA TO MANDEVILLE'S TRAVELS: UNTANGLING THE MISATTRIBUTED IDENTITIES AND WRITINGS OF JOHN OF BURGUNDY
}

\begin{abstract}
In a recent article, Patrick Outhwaite discusses censorship in 'two previously unknown early sixteenth-century manuscript copies of the Middle English translation of the Practica phisicalia, the recipe book of John of Burgundy (circa 1338-1390).' While this authorial attribution is problematic, it is in fact only the latest instance in a long tradition of mis-crediting works to a fourteenth-century physician known as John of Burgundy, John with the beard (à la barba, cum barba, von barba) or, in some texts, John of Bordeaux. John's name has been attached to the most widely circulated plague treatise in late-medieval and early-modern England, but also has been misattributed to a number of other medical texts, both historically and in recent years. What complicates matters further is that this same 'John of Burgundy' has been hopelessly tied up with what is now considered to be a fictional work: Mandeville's Travels. He is sometimes identified as the real author of the work, sometimes as the narrator, and in other instances as a physician encountered by the narrator. Here we attempt to unpack what is known about the historical John of Burgundy, how a variety of medical works came to bear his name, and why modern scholars need to be wary of such attributions.
\end{abstract}

The most commonly attested plague treatise surviving from late medieval Europe is the one usually attributed to John of Burgundy/John of Bordeaux. It survives in more than one hundred manuscript copies in several different languages (Latin, French, English, Dutch, and Hebrew) and in multiple distinct versions, including a shortened Middle English version that survives in about fifty manuscripts. ${ }^{2}$ Almost all

\footnotetext{
${ }^{1}$ Patrick Outhwaite, 'Two Manuscripts of the Practica Phisicalia Magistri Johannis de Burgundia and their Censorship', JEBS, xxi (2019), 251.

${ }^{2}$ Most copies of the Middle English short version name the author as John of Bordeaux. However, three copies (Oxford, Bodleian Library, Ashmole MSS 1444 and 1481, and London, British Library, Sloane MS 965) that contain interpolations typical of John Shirley name the author as John of Burgundy. John Shirley is generally considered to be reliable in the information he supplied about authors such as Lydgate (see Margaret Connolly, John Shirley: Book Production and the Noble Household (Farnham, 1998)). His likely motive for changing the plague tract attribution is that he believed John of Burgundy to be the correct name. However, it is quite possible that he simply had a copy of the Latin long version in his possession and believed that the tracts were related. Shirley's authorial attribution - 'This saide tretys compiled and /studied bi this sayd maiste iohn de/burgoyn [pro]fessoure of phisyk and of surgerie Citeseyn of leeges the yere/ of oure lorde a thousande thre hundred sixti and fyve.' (Sloane MS 965, f.130r) - very closely matches the wording in the longer version of the tract. One later English adaptation, attributed to the Dominican friar Thomas Multon (dated to the third quarter of the fifteenth century) subsequently appeared in print
} 
This is the authors' original version (AOV). This article has been accepted for publication in Notes \& Queries Published by Oxford University Press.

of these can be traced to English or Scottish production, a mark of the tract's special popularity (and lack of competition) in those kingdoms. Dating from the last quarter of the fourteenth century until well into the seventeenth, copies of this treatise can be traced to religious, secular, and commercial sites across England, France, and the Low Countries, as well as to the French and English royal courts. ${ }^{3}$ More popular, it seems, than the plague tracts written by higher status and better-known fourteenth-century authors - such as the Paris Medical Faculty, several chancellors from the Montpellier medical faculty, and papal physicians ${ }^{4}$ - John of Burgundy's work and the man himself have been the subject of historical and literary interest since the late fourteenth century.

Despite this attention, little is known for certain about who John of Burgundy actually was. He has not been identified with any historical person outside the problematic scholarship attempting to identify the historical Sir John Mandeville. The information that is most likely to be accurate comes from the treatise that bears his name, the earliest datable surviving copy of which was produced in 1371, in French, six years after the treatise was purportedly composed in 1365 (Paris, BNF fonds français, nouvelle acquisition MS 4516).

Near the beginning of this treatise, in a section that Dorothea Waley Singer called the 'personal introduction', John tells us that he is a physician and professor in the art of medicine in the city of Liège. Otherwise known as 'the bearded/with the beard' ${ }^{6}$ John wrote his treatise in 1365 following the first major post-Black Death recurrence of plague in that city. He further states that he is writing for "prayers not profit' ${ }^{7}$ and makes several local references, including to a successful medical recipe that can only

within a larger medical compendium between the late 1520s and 1580 (Thomas Moulton, This is the Myrour or Glasse of Helthe (London: <1530)). A Dutch translation (of the longer original version) also appeared in a printed medical compendium between 1530 and 1622, correctly attributed to 'Ioannes van Bourgondien anders metten barde ghenaemt een borghere van Luydick'. Anonymous, Tfundament der medicinen ende chyrurgien (Antwerp, 1530).

${ }^{3}$ Lori Jones, 'The Itineraries and Many-Faceted Lives of John of Burgundy's Plague Treatise', (BMH, forthcoming); Lori Jones, Time, Space, and the Plague: Rereading English and French Plague Tracts, 1348-1750 (under contract, forthcoming); Alpo Honkapohja, Alchemy, Medicine, and Commercial Book Production: A Codicological and Linguistic Study of the Sloane Manuscript Group (Turnhout, 2017); Lister M. Matheson, 'Médecin sans Frontières? The European Dissemination of John of Burgundy's Plague Treatise', $\underline{\text { ANQ, }}$ xviii.3 (2005), 19-31.

${ }^{4}$ The oft-cited and influential tract of the Paris Medical Faculty, written in 1348 at the behest of France's King Philip VI, survives in about twenty-five manuscript copies, while that of Montpellier Medical Faculty Chancellor Johannes Jacobi (Jean Jacme) survives in about forty. Both circulated primarily in Latin.

${ }^{5}$ Dorothea Waley Singer, 'Some Plague Tractates (Fourteenth and Fifteenth Centuries)', Proceedings of the Royal Society of Medicine, ix (1916), 204. For a modern English translation, see Rosemary Horrox, The Black Death (Manchester/New York: 1994), 184-93. Horrox's translation uses the edition found in Karl Sudhoff, 'Pestschriften aus des ersten 150 Jahren nach der Epidemie des ,schwarzen Todes“ 1348. III. Aus Niederdeutschland, Frankreich und England' Archiv für Geschichte der Medizin, v.1/2, 58-70, which itself is based primarily on the copy found in Erfurt, Amplonian MS Q.192, ff.146r-148v. 6 'Jehan de Bourgoigne autrement dit a la Barbe'. Paris, BNF, fonds français, nouvelle acquisition MS 4516, fol. 97r. A digitized facsimile of the manuscript is available online: https://gallica.bnf.fr/ark:/12148/btv1b84557895 (accessed 25 September 2019).

7 'Non pour pris mais pour prieres ai ceci fait'. BNF MS 4516, f.102v. In Latin: 'non pro precio sed p[ro] p[re]cib[us]'. Oxford, Bodleian Library, Ashmole MS 1443, f.375r. 
This is the authors' original version (AOV). This article has been accepted for publication in Notes \& Queries Published by Oxford University Press.

be manufactured by a certain apothecary in Liège and a less efficacious one that was originally sent in a letter from Cologne to Liège (or, according to some copies of the tract, to Lyon). In his personal introduction, John also mentions having written two earlier treatises, one on the nature of corrupt air and the other about epidemic versus other types of diseases. 'Anyone who has copies', he wrote, 'will find many things in these treatises about lifestyle and cures. ${ }^{8}$ These two treatises have not survived, or at least remain undiscovered. ${ }^{9}$

Information about John of Burgundy that is sometimes cited as factual is, possibly, simply based on interpretations of this personal introduction. In his 1903 translation and edition of the Latin manuscript Erfurt MS Amplonian Q 192, Georg Guttmann wrote that Jean à la Barbe worked from 'about 1330 to 1370 ' as a professor of medicine in Liége and was a popular and respected physician, teacher and writer. ${ }^{10}$ The dates seem to be Guttman's estimate of the years when à la Barbe was active, while the rest of the information simply paraphrases and interprets what John said himself in his plague tract's personal introduction. More recently, Joseph Byrne's Encyclopedia of the Black Death provides birth and death details for John of Burgundy — '(c. 1338 - 1390)' — with neither a reference for nor a validation of the dates. $^{11}$

Since the fifteenth century, other medical texts have been attributed to John of Burgundy spuriously. Some of these erroneous attributions likely resulted from the way the plague tract was typically placed in late medieval and early modern medical miscellanies and anthologies: squeezed into blank folios or added to empty spaces, sometimes with little internal marking to clearly distinguish it from the texts that preceded or followed. The second of two Middle English Northern dialect copies of John of Burgundy's tract in Oxford Bodleian Additional A.106 (ff.120r-122v) is easy to miss, for example, since it begins in the middle of f.120r with neither a heading nor any rubric to indicate the beginning of the text. In Durham Cosin MS V.III.10, rhyming couplets on bloodletting immediately follow a Middle English short version of the plague tract (ff.41v-43r). Similarly, in Durham Cosin MS V.IV.1, succeeding a Middle English long version of the treatise are four recipes against pestilence (f.39r). These recipes are introduced in the text (as 'Here er gode drynkes \& medicines for pe pestilence') and are not part of the treatise, but were catalogued as if they were in $1950 .^{12}$ Another interesting example of this phenomenon appears in London, British

\footnotetext{
8 'Es quelz se aucu[n]s a la copie a preseruacion \& cure pluseurs choses trouu[er]a'. BNF MS 4516, f.98r.

${ }^{9}$ Waley Singer ('Some Plague Tractates', 176) tried unsuccessfully to identify the two missing treatises by examining astrological tracts.

10 'Tatsächlich ergibt sich aus literarischen Untersuchungen, speziell dem Inhalt der nachfolgend zum ersten Mal durch den Druck veröffentlichten Handschriften, daß Jean à la Barbe etwa von 1330 bis 1370 als Professor der Medizin in Lüttich wirkte, ein beliebter und angesehener Arzt, Lehrer und Schriftsteller war.' Georg Guttmann, Die Pestschrift des Jean a la Barbe (1370): zum ersten Male herausgegeben, übersetzt und erklärt (Berlin, 1903), 7.

${ }^{11}$ Joseph P. Byrne, Encyclopedia of the Black Death, Volume 1 (Santa Barbara, 2012), 197. The two sources that Byrne references for his discussion of John of Burgundy make no mention of these dates. One notes only that 'John may have died in 1372', a date different than that provided by Byrne. Matheson, 'Médecin sans Frontières?' 21.

${ }^{12}$ For the catalogue entry, see Dorothea Waley Singer and Annie Anderson, Catalogue of Latin and Vernacular Plague Texts in Great Britain and Eire in Manuscripts Written before the Sixteenth Century (London, 1950), 45 (corrected by A.I. Doyle in 2007 in the Durham Palace Green Library's unpublished catalogue, 8 ).
} 
This is the authors' original version (AOV). This article has been accepted for publication in Notes \& Queries Published by Oxford University Press.

Library Sloane MS 405, in which it seems that a Latin version of the plague tract attributed to John of Burgundy sits amidst two sections of a long treatise on recipes. ${ }^{13}$ The plague tract opens with a clear incipit in English, but a series of English plague recipes follow the Latin text with little indication that the tract has ended other than a faded red wavy line. Because the plague tract functioned as both a regimen and a supplier of numerous recipes and therapies, it could easily be mistaken for, or blended into, other similar kinds of texts. Where the tract included an incipit or explicit attributing the text to John of Burgundy (or one of the alternative names by which he was known), but lacked a corresponding explicit or incipit to clearly indicate the beginning or end of the text proper, boundaries between the plague treatise and other works were easily blurred.

We see, therefore, several manuscripts in which authorship has been granted to John of Burgundy (or one of his aliases) for otherwise anonymous texts or ones attributed to other authors elsewhere. A late-fifteenth century German manuscript (Heidelberg Library Cod. Pal. germ. 228) mentions 'Pulvers in Das Grosse Kunst Buch von Barba'. ${ }^{14}$ A copy of John Mirfield's late-fourteenth-century Governal of Health regimen found in the fifteenth-century London, British Library, Sloane MS 989 includes John of Burgundy among a long list of authoritative authors on whose writings the regimen was apparently based. ${ }^{15}$ At the end of several chapters added to the regimen, on $\mathrm{f} .133 \mathrm{v}$, the text concludes with these words: "And here endith this tretyse. This lytel boke compyled [by] a worthi clerke called John de Burdeux for a frende that he had.'Although this specific manuscript does not also contain a copy of the plague tract, it may have been copied from an earlier one like Oxford, Bodleian Library, Ashmole MS 1481 that did include both texts. The collection of English recipes entitled Practica physicalia discussed by Outhwaite also appears in Oxford, Bodleian Library, Rawlinson MS D.251 (ff.72v-113r), dated to the first half of the fifteenth century, along with an attribution to 'magistri Johannis de Burgundia'. ${ }^{16}$ An astrological tract from the late-fifteenth century (Oxford, Bodleian Library, Ashmole MS 340, ff.45v-54r) is credited to John of Burgundy, ${ }^{17}$ as are two tracts on phlebotomy and urine (Oxford, St. John's College MS 172). ${ }^{18}$

\footnotetext{
${ }^{13}$ It is, unfortunately, extremely difficult to determine the original pagination of this manuscript, as the leaves are bound tightly and any signatures have been lost to cropping. However, medieval foliation runs until f.107 (with no errors in order, except for eleven missing leaves) and the decoration is similar throughout. There is thus good reason to assume these leaves were together in the Middle Ages in a collection foliated by the medieval compiler or owner.

${ }^{14}$ Noted in Waley Singer, 'Some Plague Tractates', 177.

${ }^{15}$ In reality, Mirfield based the larger compendium in which the regimen appears on the works of 'John of Gaddesden, Bernard Gordon, Avicenna, Constantine the African, Galen, Hippocrates, Gilbertus Anglieus, Platearius, and Mesue ...[plus] short bits attributed to wellknown Englishmen of his time, such as Bartholomaeus Anglicus, Oxford physician Nicholas Tyngewick, and even Robert Grosseteste.' Faye Getz, 'John Mirfield and the Breviarium Bartholomei: The Medical Writings or a Clerk at St Bartholomew's Hospital in the Later Fourteenth Century', SSHM, xxxvii (1985), 25-26.

${ }^{16}$ Outhwaite mentions this manuscript, but does not discuss its purported link to John of Burgundy.

${ }^{17}$ Noted in Lister M. Matheson, 'John of Burgundy: Treatises on Plague', in M. Teresa Tavormina (ed.), Sex, Aging, and Death in a Medieval Medical Compendium. Trinity College Cambridge MS R.14.52, Its Texts, Language, and Scribe (Tempe, 2006), II, 570.

${ }^{18}$ Noted in Ernst Wickersheimer, Dictionnaire biographique des médecins en France au
} 
This is the authors' original version (AOV). This article has been accepted for publication in Notes \& Queries Published by Oxford University Press.

In some cases, the bearded Burgundian could not possibly have written the text attributed to him, because it was extant in earlier centuries. The sixteenth-century London, British Library, Sloane MS 2507 both contains a copy of John of Burgundy's plague tract and attributes to him Peter of Spain's thirteenth-century Thesaurus Pauperum, a recipe book dealing with issues of contraception and menstruation. Even the later-twelfth-century Trotula - a popular compendium of texts addressing women's medicine - sees itself credited to 'John of Burgwen' in at least one English translation in the sixteenth-century Longleat House (Warminster, Wiltshire), MS Longleat 333 (ff. 33r-43v). ${ }^{19}$ At the same time, we also find medical texts attributed to John Mandeville. Waley Singer pointed to at least six manuscripts that contain recipes attributed to him, while Ernst Wickersheimer noted several copies of a lapidary (in both Latin and French, manuscript and print) credited to Mandeville. ${ }^{20}$

These historical misattributions are not necessarily troubling on their own, since unattributed translation, adaptation, and copying were common in late medieval and early modern Europe, as were the appropriation and reassignment of textual authorship. ${ }^{21}$ The problem arises when nineteenth- and early-twentieth century writers took such misattributions as truth, and then modern scholars and library databases repeat them. ${ }^{22}$ Based on an attribution to 'John of Burdeux' in a single fifteenthcentury manuscript copy of the Governal of Health, that is, BL Sloane MS 989, William Blades determined in the mid-nineteenth century that John of Burgundy was the author of the printed edition that he (Blades) analysed and reproduced. ${ }^{23}$ Later studies of the regimen have correctly noted Mirfield's authorship, but the British Library's online manuscript catalogue still records John of Burgundy/Bordeaux as the text's author, as does the Voigts-Kurtz online database. ${ }^{24}$ The British Library's catalogue likewise repeats the mistaken attribution for its copies of the Thesaurus Pauperum found in two different manuscripts. ${ }^{25}$

Moyen Age (Geneva: 1979 (first published Paris, 1936)), 370. The volume was updated by Danielle Jacquart in 1979, but we use Wickersheimer here as the author since his entries on John of Burgundy/John Mandeville were not updated.

${ }^{19}$ Noted in Monica H. Green, 'A Handlist of the Latin and Vernacular Manuscripts of the SoCalled Trotula Texts. Part II: The Vernacular Translations and Latin Re-Writings', Scriptorium li (1997), 87-88.

${ }^{20}$ Waley Singer, 'Some Plague Tractates', 177; Wickersheimer, Dictionnaire, 370.

Wickersheimer disputed one manuscript's claim that Mandeville was Philip the Fair's surgeon, correcting this to Henri Mandeville, not John.

${ }^{21}$ Alistair Pennycook, 'Borrowing Others' Words: Text, Ownership, Memory, and Plagiarism,' TESOL Q xxx.2, (1996), 205

${ }^{22}$ This is a problem akin to the modern mislabeling of medieval medical and disease images discussed in Lori Jones and Richard Nevell, 'Plagued By Doubt and Viral Misinformation:

The Need for Evidence-Based Use of Historical Disease Images,' Lancet Infect Dis xvi.10, (2016), e235-e240.

${ }^{23}$ Willam Blades, Gouernayle of Helthe: With The Medecyne of $\mathrm{y}^{\mathrm{e}}$ Stomacke. Reprinted from Caxton's Edition (London, 1858), 4-5.

${ }^{24}$ Linda Ehrsam Voigts and Patricia Deery Kurtz, Scientific and Medical Writings in Old and Middle English: An Electronic Reference, eVK2 $<\mathrm{http} / /$ cctr1.umkc.edu/search $>$, items eVK2 0619.00, 3763.00, 6777.00, 6667.00, 6718.00, 6790.00, 3154.00, 4037.00, 1128.00, 0951.00, and 3940.00, covering Sloane MS 989 ff.34-132.

${ }^{25}$ British Library, 'Explore Archives and Manuscripts', entries for Sloane MS 989,

Additional MS 29301, Sloane MS 2507, (accessed 13 August 2019). By contrast, the 
This is the authors' original version (AOV). This article has been accepted for publication in Notes \& Queries Published by Oxford University Press.

In Outhwaite's article, we find not only the repetition of a false authorial credit, but unverified birth and death details for the purported author. The article notes that the two manuscript copies that it attributes to John of Burgundy have been unacknowledged until now 'because they contain no reference to the title of the work or its author. ${ }^{26}$ Relying on Fritz Heinrich's analysis and edition of the text from 1896, the article accepts the authorial attribution, despite the lack of evidence that John had anything to do with it. ${ }^{27}$ Crucially, Heinrich himself did not assign the tract's authorship to John of Burgundy, nor does John of Burgundy's name appear in the manuscript text from which Heinrich made his edition. ${ }^{28}$ Outhwaite's article does not mention that the copy of the Practica phisicalia in London, British Library, Sloane MS 405 appears alongside (in fact, split in parts around) a plague tract that is correctly attributed to John of Burgundy. This type of text-splitting, together with the incorrect attribution to John found in Oxford, Rawlinson MS D.251, may have either caused confusion among later copyists (and modern editors and catalogers) about who authored the Practica. Alternatively, recognizing the author's popularity because of the plague treatise, they were inspired to give John credit for more than he actually wrote.

Relying just on these misattributions, we might conclude that the type of miscrediting that connected John of Burgundy through a popular, widely-circulated plague treatise to other, similarly utilitarian and widespread medical texts was not entirely unusual. What is more unusual, though, is how the Liège physician was turned into what can perhaps best be described as a mysterious and romantic literary character in works known for blending fact with fiction. He is mentioned in some versions of the popular travelogue known as Mandeville's Travels, which was once considered to be authoritative - both Prince Henry the Navigator and Christopher Columbus purportedly carried a copy on their voyages - but is by modern scholarship considered to be 'a literary hoax of impressive proportions. ${ }^{\text {, }}$ The earliest extant and dated versions of both John of Burgundy's plague tract and John Mandeville's Travels appear in the same manuscript: a lavishly decorated French volume commissioned for French King Charles V by his physician Gervaise Crestien in 1371 (BNF, MS 4515-4516). The same scribe, Raoulet d'Orléans, copied all the texts in the manuscript, and the illustrations are consistent throughout. ${ }^{30}$ This may well be one of the impetuses behind the blending of the two men. In fact, an early-

Wellcome Collection lists Burgundio de Pisa, a twelfth-century Italian jurist, as the author of two fifteenth-century Latin copies of John of Burgundy's tract in its collection (MS 550, ff. 108r-115r and MS 548, ff. 58v-62r).

${ }^{26}$ Outhwaite, 'Two Manuscripts', 251.

${ }^{27}$ Fritz Heinrich, ed., Ein Mittelenglisches Medizinbuch (Halle, 1896).

${ }^{28}$ Outhwaite suggests that Heinrich's source text, the fifteenth-century London, British Library Additional MS 33996, attributes the work to John of Burgundy. It does not. Heinrich's edition does include two mentions of the name 'Johannes,' in the middle of prayers, but here they invoke John the Baptist or another religious figure. There is no suggestion that Johannes is John of Burgundy.

${ }^{29}$ Ralph Hanna, 'Mandeville' in A.S.G. Edwards (ed.) Middle English Prose: A Critical Guide to Major Authors and Genres (New Brunswick, NJ, 1984), 123. Mandeville's Travels remained a popular work for centuries - there are translations in Middle English, German, Italian, Dutch, Spanish, and Latin, new editions were printed, and it seems to have been read until at least the eighteen century.

${ }^{30}$ The manuscript's foliation suggests that it was once a single compilation, but after being rebound at the BNF in the nineteenth century it now exists as two separate volumes. 
This is the authors' original version (AOV). This article has been accepted for publication in Notes \& Queries Published by Oxford University Press.

modern hand notes at the bottom of the first folio of Mandeville's Travels that 'Messire Jean de Mandeuille' was, among other things, a 'Docteur en Medicine.' 31

Mandeville's Travels contains several mentions, some of them contradictory, of a widely travelled and learned bearded physician residing in Liège. ${ }^{32}$ Most copies of this narrative treat Mandeville and the physician as two different characters, mentioning that the two men at least knew each other, having met once in the sultan's court while travelling in Egypt, and then again later in Liège. Others note that Mandeville only met de Barba after returning to Liège suffering from arthritic gout. Having consulted all the physicians in the city, 'there came to' Mandeville 'one physician, more venerable than all the others by reason of his age and his grey hair, evidently skilful in his art, who was there called Master John with the Beard.' 33 This source is thus somewhat unclear about any actual relationship between the two, and later studies of the tale conflate the physician with the author.

There certainly are signs that John of Burgundy and John Mandeville were viewed as being the same person already before the early fifteenth century. A fellow resident of Liège, Jean d'Outremeuse (1338-1400), wrote both a legendary history of that city called La Geste de Liége and a general history known as Ly Myrour des Histors (Mirror of Histories). Like John of Burgundy, d'Outremeuse has also been suggested as a candidate for the author of Mandeville's Travels. ${ }^{34} \mathrm{D}$ 'Outremeuse is said to have acted as a deathbed testamentary executor for a friend 'known by the name of Jean de Bourgogne, called "with the beard." ${ }^{35}$ His dying friend was 'a great naturalist, a profound philosopher and astrologer', but as he read the will d'Outremeuse realised that the man's real name was 'Jean de Mandeville, Knight, Count of Montfort in England, lord of the isle of Campdi and of Château Perouse.' ${ }^{36}$ Wording ostensibly found on John of Burgundy/John Mandeville's tombstone has been cited to corroborate his confession. ${ }^{37}$

There are problems with this account, however. D'Outremeuse definitely was active in Liège, where John of Burgundy composed his plague treatise. The two were contemporaries and it is hard to imagine how they would not have met, considering how small medieval cities were in northern Europe and the even smaller number of inhabitants there would have been with literary and scholarly ambitions. Malcolm Letts noted that 'In his [...] references to the "Travels" d'Outremeuse always speaks of the author as Mandeville. ${ }^{38}$ D'Outremeuse cannot, however, be considered as a reliable source at all: while he did use sources, he did not discriminate between chronicles and romances. He 'disfigures or invents proper names, alters numbers and circumstances to the despair of those honest commentators who have traced him to his sources. ${ }^{39}$ It is therefore extremely difficult to know what to make of these

\footnotetext{
${ }^{31} \mathrm{BNF}, \mathrm{MS} 4515$, f.1r.

${ }^{32}$ For a good overview in modern English translation, see Malcolm Letts, Mandeville's Travels: Texts and Translations (London, 1953), I, xxvii.

${ }^{33}$ Letts, Mandeville's Travels, $x x$.

${ }^{34}$ Paul Hamelius, Mandeville's Travels, from MS. Cotton Titus C.xvi, I and II, EETS 153 \& 154 (Oxford, 1919 \& 1923), I, 8-13.

${ }^{35}$ Ibid., I, xix.

${ }^{36}$ Cited in Letts, Mandeville's Travels, xix.

${ }^{37}$ The English chronicler Thomas Walsingham took as truth Mandeville's claim to have been from St. Albans.

${ }^{38}$ Ibid., xxi.

${ }^{39}$ Hamelius, Mandeville's Travels, I, 8-10. He also has been shown to have faked an
} 
This is the authors' original version (AOV). This article has been accepted for publication in Notes \& Queries Published by Oxford University Press.

references to John of Burgundy/Mandeville. In fact, and more telling, the story of John's deathbed confession to d'Outremeuse does not even come from surviving manuscripts of d'Outremeuse's own chronicle. Rather, they are told first by Louis Abry (1643-1700), a seventeenth-century Liégeois herald and antiquary who claimed to have seen a 'lost' fourth book of the work. Each citing the other in succession, nineteenth-century writers took Abry's claim at face value and inserted it into their own editions of either d'Outremeuse's work or Mandeville's Travels; one even said 'There seems no reason to doubt the authenticity' of the deathbed confession story, even though there was no way to verify it. ${ }^{40}$ Yet it seems possible that d'Outremeuse did not write all the books of his chronicles himself; rather, some parts - possibly even the lost fourth book-were written by another Liégeois chronicler, Jean de Stavelot, after d'Outremeuse's death. And it was in de Stavelot's copy of d'Outremeuse's chronicle that Abry purportedly found the deathbed confession. ${ }^{41}$

Another chronicler who died in 1403, Radulphus de Rivo, the Dean of Tongeren (located about ten miles/sixteen km from Liège), named Mandeville in his work, describing him as 'vir ingenio et arte medendi eminens' (a man of outstanding ability and the art of healing) who was buried among the Guillemites. De Rivo claimed that Mandeville had written his Travels in three languages. In his analysis of Mandeville's Travels, Letts eagerly pointed out that de Rivo 'was practically a contemporary with no axe to grind', but acknowledged that he was writing at least two decades after the earliest dated manuscripts containing the texts of John of Burgundy and Mandeville appeared. He was far more likely to have known d'Outremeuse than Mandeville who, de Rivo claimed, had died in $1367 .{ }^{42}$ A third chronicler, a Benedictine of St. Jacques at Liège named Cornelius Zantfliet (d. c.1461), referred to Mandeville as 'aliter cum Barba' and 'in arte medicinae peroptime tritus' (otherwise with a beard, and best practiced or skilled in the art of medicine).

There are numerous travel reports that mention Mandeville/John of Burgundy's tomb in Liège in the church of Guillemites that was later destroyed during the French Revolution. The earliest dates from 1462 (about century after John of Burgundy had composed his plague treatise), while the others are from the sixteenth and eighteenth centuries. Each account differed in some details, but in the early-twentieth century the Belgian philologist Paul Hamelius used them to reconstruct the headstone inscription: 'Hic jacet nobilis Dominus Joannes de [Mandeville] miles, alias dictus ad Barbam, Dominus de [Camperdi], natus [in] Anglia, medicinae professor et devotissimus orator et bonorum [suorum] largissimus pauperibus erogator, qui [toto quasi orbe lustrato] Leodii diem vitae suae clausit extremum anno [Domini] millesimo trecentesimo septuagesimo secondo mensis Februarij septimo. ${ }^{43}$ [Here lies the noble Lord John [Mandeville], soldier, otherwise called the Bearded, from [Camperdi], born [in] England, a professor of medicine and a devoted orator and generous benefactor to the poor, who having travelled the world, came to the end of his life in Liège. The year [of our Lord] one thousand three hundred and seventy-two, the seventeenth day

aristocratic name for himself. See pp. 11-13 for arguments that d'Outremeuse was the author of Mandeville's Travels. For a recent discussion on the historicity of d'Outremeuse, see Pierre Courroux, 'Godefroid Kurth et Jean d'Outremeuse : un historien du XXe siècle face à l'invention historique.' Médiévales lxiv (2013), 153-172.

${ }^{40}$ Letts, Mandeville's Travels, xix.

${ }^{41}$ Stanislas Bormans, Ly myreur des histors (Brussels, 1864), cxxxii-cxxxiii.

${ }^{42}$ Letts, Mandeville's Travels, xxiii.

${ }^{43}$ Hamelius, Mandeville's Travels, I, 1-3, inscription on 2. 
This is the authors' original version (AOV). This article has been accepted for publication in Notes \& Queries Published by Oxford University Press.

of February]. ${ }^{44}$ Hamelius argued that the survival of several independent descriptions from a period stretching across more than 300 years was not likely to be a fabrication; it was thus safe to conclude, he felt, that a tomb existed for Mandeville already in the fifteenth century. As the epitaph no longer exists, however, it is impossible to determine when it was erected, or by whom. Perhaps the monument or at least the inscription were added years later, when Mandeville's Travels had become something of a medieval bestseller and its author was already a mysterious celebrity. Many travelers would have read Mandeville's Travels. Liège has been described as situated at the 'crossroads of Europe', ${ }^{45}$ erecting the tombstone as a tourist attraction is not a farfetched idea.

Hamelius furthermore inspected local documents connected to the abbey and discovered that real property records from 1386 included a 'Mestre Johan ale Barbe'. Some seventy years later, in 1459, the same house was noted as being the home of 'la Mandavele ly chevalier d'Engleterre qui avoit esteit par universe par universe monde solloit demoreir, qui gist a Willmins.' In other words, it purportedly was where Mandeville used to live. ${ }^{46}$ It is worth noting, though, that the earlier document, dated fifteen years after the oldest dated manuscript containing the plague tract and Mandeville's Travels, mentions neither the name 'Mandeville' nor that John-with-thebeard was a 'Knight of England' (or even a doctor of physic for that matter).

Reference to a bearded John in Liège could possibly be our John of Burgundy, but the association to Mandeville was false. If Mandeville died in 1372, as the tombstone indicates, or in 1367 as de Rivo claimed, who associated him with Bearded John's house almost a century later?

The purported link between John of Burgundy and Mandeville was, and has remained, popular. It has even been implicated in studies of the plague tract. David Murray's late nineteenth-century work on the copy of the tract found in the Scottish Black Book of Paisley and its relationship to other copies of the tract known at the time took the association between the two men for granted. Indeed, the very title of his work makes this fusion clear: John de Burdeus, or John de Burgundia, Otherwise Sir John de Mandeville and the Pestilence. Murray notes his conviction that John of Burgundy was in fact an Englishman. ${ }^{47}$ Waley Singer, writing some decades later, was also convinced that the two men were the same person, noting 'the research of the last fifty years has fairly established his [John of Burgundy's] authorship of the original version of the "Travels of Sir John Mandeville." 48 In his biography of medieval French physicians, Ernst Wickersheimer also repeated the relationship, only

\footnotetext{
${ }^{44}$ Hamelius translated 'devotissimus orator' as 'very pious in his prayers.' Subsequent writers have followed this tradition. While orator can mean one who prays, this sense most commonly refers to those who pray for a living (that is, monks or other clerics). Since the Latin "orator" can also mean an actual orator or speaker, we have elected to use that translation as it makes more sense in the context in which it is used to describe Mandeville, as a medical professor. We are grateful to Carmen Cardelle de Hartmann for her assistance with mediaeval Latin formulae.

${ }^{45}$ S. Vanderputten, T. Snijders, and J. Diehl, eds., 2017. Medieval Liège at the Crossroads of Europe Monastic Society and Culture, 1000-1300 MCS 37 (Turnhout, 2017).

${ }^{46}$ Hamelius, Mandeville's Travels, I, 2-3.

${ }^{47}$ David Murray, John de Burdeus, or John de Burgundia, Otherwise Sir John de Mandeville and the Pestilence (Paisley and London, 1891), 14-19. Murray also repeats the attribution to John of Burgundy of the Regimen of Health and Thesaurus Pauperum discussed above.

${ }^{48}$ Waley Singer, 'Some Plague Tractates', 161
} 
This is the authors' original version (AOV). This article has been accepted for publication in Notes \& Queries Published by Oxford University Press.

tempering the assertion slightly by saying 'If we believe the chronicler Jean d'Outremeuse'. ${ }^{49}$ Even relatively recently, some scholars have continued to accept that the two were the same man. In his study of a fifteenth-century adaptation of John of Burgundy's plague tract, George R. Keiser notes that John was 'known also as John of Bordeaux, John de la Barbe, and John Mandeville'. ${ }^{50}$ French language biographies of medieval notables and scholarship on Mandeville's Travels say much the same. ${ }^{51}$ Both the English and French Wikipedia pages on John Mandeville/Jean de Mandeville claim that it is 'beyond doubt' that his real name was Jean de Bourgogne (Jehan à la Barbe) and that he was a physician. ${ }^{52}$

While nineteenth and early-twentieth century scholars spent years trying to find the historical Mandeville, though, he has proven to be elusive. Several people were called Mandeville, but details of their lives cannot be matched with the particulars offered in the narrative travel (which in any event vary considerably in their various copies). Nor do descriptions of the Mandeville/John of Burgundy tomb match any known Mandeville coat of arms. To make things more complicated, there are several historical people known as John of Burgundy, including dukes and an archbishop. ${ }^{53}$ None of these men fit our time frame exactly, but the point here is that John/Jean/Johannes was a common Christian name and Burgundy can refer to vast area. Most men were able to grow a beard.

Most later-twentieth- and twenty-first century English scholarship has, by contrast, been sceptical about the very existence of a historical Sir John Mandeville. ${ }^{54}$ This

\footnotetext{
${ }^{49}$ Wickersheimer, Dictionnaire, 369. Wickersheimer also mentioned claims made in the mideighteenth century that Mandeville was regent of the Paris Medical Faculty in 1332.

${ }^{50}$ George R. Keiser, 'Two Medieval Plague Treatises and their Afterlife in Early Modern England', J. Hist. Med. Allied Sci. Lviii.3 (2003): 299. See also

${ }^{51}$ Robert Bossuat, Louis Pichard, and Guy Raynaud de Lage, Dictionnaire des Lettres Françaises: Le Moyen Age (Paris, 1992), 810; Xavier Walter, Avant les grandes découvertes: Une image de la Terre au XIV ${ }^{\mathrm{e}}$ siècle, Le voyage de Mandeville (Roissy-en-France, 1997), 7, $17-8$.

${ }^{52}$ Wikipedia, 'John Mandeville' https://en.wikipedia.org/wiki/John_Mandeville, and 'Jean de Mandeville', https://fr.wikipedia.org/wiki/Jean_de_Mandeville, (accessed 20 September 2019).

${ }^{53}$ A cursory online search, for example, indicates that following men were known as John of Burgundy/Jean de Bourgogne: Jean de Bourgogne (1190-1267), comte de Châlon; Jean de Bourgogne (1231-1268), seigneur de Bourbon; John I of Viennois (1263-1282), member of the House of Burgundy and Dauphin of Viennois; Jean de Bourgogne (d.1302), seigneur de Montaigu; Jean sans Peur (1371-1419), duc de Bourgogne; Jean de Bourgogne (1404?1479/80), Bishop of Cambrai and Archbishop of Trier; Jean de Bourgogne (1403-1427), duc de Brabant; and Jean de Bourgogne (1415-1491), comte d'Étampes, de Nevers, de Rethel et d'Eu. David Murray suggests that John of Burgundy may have been 'one John de Mundeville [who] was parson of Moffat in Dumfriesshire' in 1296. Murray, John de Burdeus, 17, fn. 4. No doubt there were others.

${ }^{54}$ More recent theory is presented by John Larner, 'Plucking Hairs from the Great Cham's Beard: Marco Polo, Jan de Langhe, and Sir John Mandeville', in Suzanne Conklin Akbari, Amilcare Iannucci (eds.), Marco Polo and the Encounter of East and West (Toronto, 2008), 133-155. Larner proposes the work was composed by a Benedictine monk in Ypres, Jean le Long or Jan de Langhe, who is known for translation work and who owned many travelogues. See also Iain Macleod Higgins, Writing East: The 'Travels' of Sir John Mandeville (Philadelphia, 1997) and Hanna, 'Mandeville', both of whom dispute Mandeville's very existence. It must also be noted that there is a difference over speculating who wrote Mandeville's Travels (as per Larner) and determining whether Sir John Mandeville was a real
} 
This is the authors' original version (AOV). This article has been accepted for publication in Notes \& Queries Published by Oxford University Press.

attitude is taken also by the most recent scholar (aside from the two authors of this article) to work on John of Burgundy in detail, Lister Matheson; Matheson simply mentioned that 'modern scholarly scepticism about the true identity and biography of the latter [i.e., Mandeville] makes such an identification unlikely. ${ }^{55}$ The identification of Sir John Mandeville as John of Burgundy is thus very likely an error steeped in historical fiction and romance.

And yet, like the mis-crediting of John of Burgundy as the author of numerous medical texts, the misattribution to him of Mandeville's Travels continues in institutional library catalogues that are still the primary, if not sole, source of information about their manuscript holdings. The Bodleian Library's Summary Catalogues, for example, labels the mid-fifteenth century English copies of Mandeville's Travels in MS e. Mus. 124 and MS Douce 33 as 'the Travels of Jean de Bourgogne (Johannes de Burgundia)' and '(de Burgundia or de Barba)'. In its entries for MS Additional A.187 and MS Additional C.252, two mid-fifteenth-century manuscripts from Italy, the catalogue likewise notes that 'The real author [of Mandeville's Travels] is generally believed to be Johannes de Burgundia'. ${ }^{56}$

To sum up, what can we say? There is much confusion surrounding works attributed to an author known as a John of Burgundy. He happened to write the plague treatise that became the dominant tract especially in medieval England for almost two centuries. As the treatise could rather conveniently be joined with other related medical texts, his name found its way into numerous other works that had nothing to do with him. The only text that we can attribute to him with any certainty is the plague treatise, and scholars should be extremely cautious if some other work bears his name.

At the same time, the plague treatise itself is attributed to a number of other names, including slight orthographical variants like John of Bordeaux or John of Bardendy, or even completely different authors such as John Stanford of Sysson, Oxford physician Henry Horne, Thomas Multon, and even Galen in one case. Numerous copies of the tract also exist in several languages without any attribution at all. The name John of Burgundy does not seem to have carried much authority in Italy, as the few surviving copies that can be connected to Italy change the attribution to someone else entirely: Gandolfus of Padua and Franciscus de (la) Pergula, for example. ${ }^{57}$ Nevertheless, enough copies, including the oldest extant ones of the fourteenth century, are consistent in attributing the text to the Liège physician to make that association viable. The closeness of the textual layout and contents likewise makes it

person or a literary hoax (as Higgins and Hanna argue). Arguments about John of Burgundy and Mandeville differ from ones that argue that book was written by Jean d'Outremeuse or Jean le Long in that they propose John of Burgundy was Mandeville, not merely the author.

${ }^{55}$ Matheson, 'John of Burgundy,' II, 569.

${ }^{56}$ Falconer Madan, H.H.E. Craster, and N. Denholm-Young, A Summary Catalogue of Western Manuscripts in the Bodleian Library at Oxford II.2 (Oxford, 1937), 682; Falconer Madan, A Summary Catalogue of Western Manuscripts in the Bodleian Library at Oxford IV (Oxford, 1897), 499; Falconer Madan, A Summary Catalogue of Western Manuscripts in the Bodleian Library at Oxford V (Oxford, 1905), 572, 622.

${ }^{57}$ London, British Library, Sloane MS 3124, ff.51v-61v, and Bethesda, National Library of Medicine, MS 491, ff. respectively. Both are noted in Matheson, 'Médecin sans Frontières?' $21-22$. 
This is the authors' original version (AOV). This article has been accepted for publication in Notes \& Queries Published by Oxford University Press.

safe to attribute variants of the tract to John of Burgundy. ${ }^{58}$

The fact that Sir John Mandeville was not a historical person does not mean that 'Jehan de Bourgoigne autrement dit a la Barbe', a physician active in Liège in the mid- to late-fourteenth century and who wrote a plague treatise in 1365 that was six years later translated and presented to the king of France, was not historical either. What is needed now, is a thorough search of fourteenth-century archival sources in Liège for John à la Barbe, who was just a citizen and medical practitioner, forgetting about English knights in exile. Doing so might provide us with a few verifiable biographical details about the person who wrote the most widely copied, translated, circulated, and read plague treatise in medieval Northern Europe. For that feat alone, John of Burgundy is worth getting to know a little better. But let's be careful to not give him credit for things he may not have done.

ALPO HONKAPOHJA

LORI JONES

University of Edinburgh

Carleton University

${ }^{58}$ See Jones, 'Itineraries' for the most recent overview of the many variants of the tract. 